ҚАЗАҚСТАН РЕСПУБЛИКАСЫ

ҰЛТТЫҚ ҒЫЛЫМ АКАДЕМИЯСЫНЫН

АБАЙ АТЫНДАҒЫ ҚАЗАҚ ҰЛТТЫҚ

ПЕДАГОГИКАЛЫҚ УНИВЕРСИТЕТІНІҢ

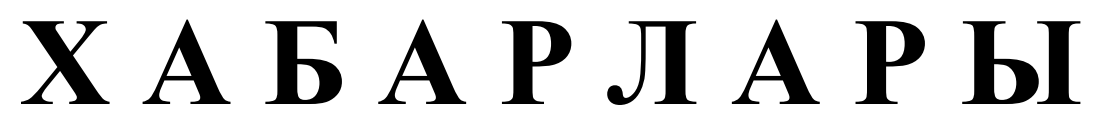

\section{ИЗВЕСТИЯ}

НАЦИОНАЛЬНОЙ АКАДЕМИИ НАУК РЕСПУБЛИКИ КАЗАХСТАН

КАЗАХСКИЙ НАЦИОНАЛЬНЫЙ

ПЕДАГОГИЧЕСКИЙ УНИВЕРСИТЕТ ИМ. АБАЯ

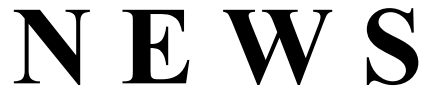

OF THE NATIONAL ACADEMY OF SCIENCES OF THE REPUBLIC OF KAZAKHSTAN

ABAY KAZAKH NATIONAL PEDAGOGICAL UNIVERSITY

ҚОҒАМДЫҚ ЖӘНЕ ГУМАНИТАРЛЫҚ ҒЫЛЫМДАР СЕРИЯСЫ

СЕРИЯ ОБЩЕСТВЕННЫХ И ГУМАНИТАРНЫХ НАУК

$\checkmark$

SERIES OF SOCIAL AND HUMAN SCIENCES

$$
5 \text { (321) }
$$

КЫРКУЙЕК - КАЗАН 2018 ж.

СЕНТЯБРЬ - ОКТЯБРЬ 2018 Г.

SEPTEMBER - OCTOBER 2018

1962 ЖЫЛДЫҢ ҚАНТАР АЙЫНАН ШЫҒА БАСТАҒАН

ИЗДАЕТСЯ С ЯНВАРЯ 1962 ГОДА

PUBLISHED SINCE JANUARY 1962

ЖЫЛЫНА 6 РЕТ ШЫҒАДЫ

ВЫХОДИТ 6 РАЗ В ГОД

PUBLISHED 6 TIMES A YEAR 
Ба с ре дактор

ҚР ҰҒА кұрметті мүшесі

Балықбаев Т.O.

Р е д а ц и я а лқ а сы:

экон. ғ. докторы, проф., ҚР ҰҒА академигі Баймұратов У.Б.; тарих ғ. докторы, проф., ҚР ҰҒА академигі Байпақов К.М.; филос. ғ.докторы, проф., ҚР ҰҒА академигі Есім Г.Е.; фил. ғ. докторы,, проф., ҚР ҰҒА академигі Қирабаев С.С.; эк. ғ. докторы, проф., ҚР ҰҒА академигі Кошанов А.К.; эк.ғ. докторы, проф., ҚР ҰҒА академигі Нәрібаев К.Н. (бас редактордың орынбасары); филос. ғ.докторы, проф., ҚР ҰҒА академигі Нысанбаев А.Н.; заң ғ. докторы, проф., ҚР ҰҒА академигі Сәбікенов С.Н.; заң ғ. докторы, проф., ҚР ҰҒА академигі Сүлейменов М.К.; эк. ғ. докторы, проф., ҚР ҰҒА академигі Сатыбалдин С.С.; тарих ғ. докторы, проф., ҚР ҰҒА академик Әбжанов Х.М.; тарих ғ. докторы, проф., ҚР ҰҒА корр. мүшесі Әбусеитова М.Х.; тарих ғ. докторы, проф., ҚР ҰҒА академик Байтанаев Б.А.; филол. ғ. докторы, проф., ҚР ҰҒА корр. мүшесі Жақып Б.А.; фил. ғ. докторы, проф., академик НАН РК Қалижанов У.К.; филол. ғ. докторы, проф., ҚР ҰҒА академик Қамзабекұлы Д.; тарих ғ. докторы, проф., ҚР ҰҒА академик Қожамжарова Д.П.; тарих ғ. докторы, проф., ҚР ҰҒА академик Койгелдиев М.К.; фил. ғ. докторы, проф., ҚР ҰҒА корр. мүшесі Кұрманбайұлы Ш.; тарих ғ. докторы, проф., ҚР ҰҒА корр. мүшесі Таймағанбетов Ж.К.; социол. ғ. докторы, проф., ҚР ҰҒА корр. мүшесі Шәукенова 3.К.; фил. ғ. докторы, проф., КР ҰҒА корр. мүшесі Дербісәлі А.; саяси. ғ. докторы, проф., Бижанов А.К., тарих ғ. докторы, проф., Кабульдинов 3.Е.; фил. ғ. докторы, проф., ҚР ҰҒА корр мүшесі Қажыбек Е.3.

\section{Р едакция ке н е с i:}

Молдова Республикасының ҰҒА академигі Белостечник Г. (Молдова); Әзірбайжан ҰҒА академигі Велиханлы Н. (Азербайджан); Тәжікстан ҰҒА академигі Назаров Т.Н. (Тәжікстан); Молдова Республикасының ҰҒА академигі Рошка А. (Молдова); Молдова Республикасының ҰҒА академигі Руснак Г. (Молдова); Әзірбайжан ҰҒА корр. мүшесі Мурадов Ш. (Әзірбайжан); Әзірбайжан ҰҒА корр. мүшесі Сафарова 3. (Әзірбайжан); э. ғ. д., проф. Василенко В.Н. (Украина); заң ғ. докт., проф. Устименко В.А. (Украина)

«Қазақстан Республикасы Ұлттық ғылым академиясының Хабарлары. Қоғамдық және гуманитарлық ғылымдар сериясы». ISSN 2224-5294

Меншіктенуші: «Қазақстан Республикасының Ұлттық ғылым академиясы» РҚБ (Алматы қ.)

Қазақстан республикасының Мәдениет пен ақпарат министрлігінің Ақпарат және мұрағат комитетінде 30.04.2010 ж. берілген № 10894-Ж мерзімдік басылым тіркеуіне қойылу туралы куәлік

Мерзімділігі: жылына 6 рет.

Тиражы: 500 дана.

Редакцияның мекенжайы: 050010, Алматы қ., Шевченко көш., 28, 219 бөл., 220, тел.: 272-13-19, 272-13-18, http://nauka-nanrk.kz. social-human.kz

(C) Қазақстан Республикасының Ұлттық ғылым академиясы, 2018

Типографияның мекенжайы: «Аруна» ЖК, Алматы қ., Муратбаева көш., 75. 
Главный редакто $p$

Почетный член НАН РК

T.O. Балыкбаев

Р е дак ци онн а я коллег и я:

докт. экон. Н., проф., академик НАН РК У.Б. Баймуратов; докт. ист. н., проф., академик НАН РК К.М. Байпаков; докт. филос. Н., проф., академик НАН РК Г.Е. Есим; докт. фил. Н., проф., академик НАН РК С.С. Кирабаев; докт. экон. Н., проф., академик НАН РК А.К. Кошанов; докт. экон. Н., проф., академик НАН РК К.Н. Нарибаев (заместитель главного редактора); докт. филос. н., проф., академик НАН РК А.Н. Нысанбаев; докт. юр. Н., проф., академик НАН РК С.Н. Сабикенов; докт. юр. н., проф., академик НАН РК М.К. Сулейменов; докт. экон. Н., проф., академик НАН РК С.С. Сатубалдин; докт. ист. н., проф., академик НАН РК Х.М. Абжанов; докт. ист. н., проф., чл.-корр. НАН РК М.Х. Абусеитова; докт. ист. н., проф., академик НАН РК Б.А. Байтанаев; докт. фил. н., проф., чл.-корр. НАН РК Б.А. Жакып; докт. фиолол. н., проф., академик НАН РК У.К. Калижанов; докт. фил. н., проф., академик НАН РК Д. Камзабекулы; докт. ист. н., проф., академик НАН РК Д.П. Кожамжарова; докт. ист. н., проф., академик НАН РК М.К. Койгельдиев; докт. филол. н., проф., чл.-корр. НАН РК Ш. Курманбайулы; докт. ист. н., проф., чл.корр. НАН РК Ж.К. Таймаганбетов; докт. социол. н., проф., чл.-корр. НАН РК З.К. Шаукенова; д. филол. н., проф., чл.-корр. НАН РК А. Дербисали; доктор политических наук, проф., Бижанов А.К.; доктор ист. наук, проф., Кабульдинов 3.Е.; доктор филол. н., проф., член-корр. НАН РК Қажыбек Е.3.

Р е дак ци онны й с ов е т

академик НАН Республики Молдова Г. Белостечник (Молдова); академик НАН Азербайджанской Республики Н. Велиханлы (Азербайджан); академик НАН Республики Таджикистан Т.Н. Назаров (Таджикистан); академик НАН Республики Молдова А. Рошка (Молдова); академик НАН Республики Молдова Г. Руснак (Молдова); чл.-корр. НАН Азербайджанской Республики Ш. Мурадов (Азербайджан), член-корр. НАН Азербайджанской Республики 3.Сафарова (Азербайджан); д. э. н., проф. В.Н. Василенко (Украина); д.ю.н., проф. В.А. Устименко (Украина)

Известия Национальной академии наук Республики Казахстан. Серия общественных и гуманитарных наук. ISSN 2224-5294

Собственник: РОО «Национальная академия наук Республики Казахстан» (г. Алматы)

Свидетельство о постановке на учет периодического печатного издания в Комитете информации и архивов

Министерства культуры и информации Республики Казахстан № 10894-Ж, выданное 30.04.2010 г.

Периодичность 6 раз в год

Тираж: 500 экземпляров

Адрес редакции: 050010, г. Алматы, ул. Шевченко, 28, ком. 219, 220, тел. 272-13-19, 272-13-18, www:nauka-nanrk.kz / social-human.kz

(C) Национальная академия наук Республики Казахстан, 2018 г.

Адрес типографии: ИП «Аруна», г. Алматы, ул. Муратбаева, 75

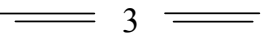


Chief Editor

\section{Honorary member of NAS RK \\ Balykbayev T.O}

Editorial board:

Doctor of economics, prof, academician of NAS RK Baimuratov U.B.; doctor of history, prof, academician of NAS RK Baipakov K.M.; doctor of philosophy, prof, academician of NAS RK Esim G.E.; doctor of philology, prof, academician of NAS RK Kirabayev S.S.; doctor of economics, prof, academician of NAS RK Koshanov A.K.; doctor of economics, prof, academician of NAS RK Naribayev K.N. (deputy editor-in-chief); doctor of philosophy, prof, academician of NAS RK Nyssanbayev A.N.; doctor of law, prof, academician of NAS RK Sabikenov S.N.; doctor of law, prof, academician of NAS RK Suleymenov M.K.; doctor of economy, prof, academician of NAS RK Satybaldin S.S.; doctor of history, prof, academician of NAS RK Abzhanov H.M; doctor of history, prof, corresponding member of NAS RK Abuseitova M.H.; doctor of history, prof, academician of NAS RK Baitanaev B.A.; doctor of philology, prof, corresponding member of NAS RK Zhakyp B.A.; doctor of philology, prof, academician of NAS RK Kalizhanov U.K.; doctor of philology, prof, academician of NAS RK Hamzabekuly D.; doctor of history, prof, academician of NAS RK Kozhamzharova D.P.; doctor of history, prof, academician of NAS RK Koigeldiev M.K.; doctor of philology, prof, corresponding member of NAS RK Kurmanbaiuly Sh.; doctor of history, prof, academician of NAS RK Taimaganbetov J.K.; doctor of sociology, prof, corresponding member of NAS RK Shaukenova Z.K.; doctor of philology, prof, corresponding member of NAS RK Derbisali A.; doctor of political science, prof Bizhanov A.K; doctor of History, prof Kabuldinov Z.E.; doctor of philology, prof, corresponding member of NAS RK Kazhybek E.Z.

\section{Editorial staff:}

Academician NAS Republic of Moldova Belostechnik.G (Moldova); Academician NAS Republic of Azerbaijan Velikhanli N. (Azerbaijan); Academician NAS Republic of Tajikistan Nazarov T.N. (Tajikistan); Academician NAS Republic of Moldova Roshka A. (Moldova) Academician NAS Republic of Moldova Rusnak G. (Moldova); Corresponding member of the NAS Republic of Azerbaijan Muradov Sh. (Azerbaijan); Corresponding member of the NAS Republic of Azerbaijan Safarova Z. (Azerbaijan); Associate professor of Economics Vasilenko V.N. (Ukraine), Associate professor of Law Ustimenko V.A. (Ukraine)

News of the National Academy of Sciences of the Republic of Kazakhstan. Series of Social and Humanities. ISSN 2224-5294

Owner: RPA "National Academy of Sciences of the Republic of Kazakhstan" (Almaty)

The certificate of registration of a periodic printed publication in the Committee of information and archives of the Ministry of culture and information of the Republic of Kazakhstan N 10894-Ж, issued 30.04.2010

Periodicity: 6 times a year

Circulation: 500 copies

Editorial address: 28, Shevchenko str., of. 219, 220, Almaty, 050010, tel. 272-13-19, 272-13-18, www:nauka-nanrk.kz / social-human.kz

(C) National Academy of Sciences of the Republic of Kazakhstan, 2018

Address of printing house: ST "Aruna", 75, Muratbayev str, Almaty 
N E W S

OF THE NATIONAL ACADEMY OF SCIENCES OF THE REPUBLIC OF KAZAKHSTAN

SERIES OF SOCIAL AND HUMAN SCIENCES

ISSN 2224-5294

https://doi.org/10.32014/2018.2224-5294.22

Volume 5, Number 321 (2018), $126-136$

UDK 342.7(574)

D.M. Baimakhanova, D.A. Ospanova

Al-Farabi Kazakh National University, Kazakhstan, Almaty

dina 405@mail.ru; azizkhan_0606@mail.ru

\title{
CONSTITUTIONAL AND LEGAL CONSCIOUSNESS AS AN IMPORTANT COMPONENT OF CONSTITUTIONALISM AND ITS ROLE IN THE SOLUTION OF HUMAN RIGHTS PROBLEMS
}

\begin{abstract}
Annotation. Article is devoted to the research of the part of society's legal sense which is turned to the constitutional sphere of regulation, performs functions on ensuring normal functioning of fundamental human rights. It is caused by the fact that the constitutional sector of the legal consciousness of society ensures the demonstration of the role and place of human rights both in the life of the latter and in the development of society as a whole, provides an epistemological explanation for the process of their formation, improvement and implementation, reveals the forms of their constitutional mediation, support and creation of favorable conditions for implementation, prepares public opinion for reforms and reforms in the field of human rights, promotes an understanding of each priority given direction of the state.

Keywords: Constitution, constitutionalism, constitutional and legal consciousness, constitutional ideology, constitutional psychology, rights and freedoms of the person, rights and freedom of the citizen of the Republic of Kazakhstan.
\end{abstract}

According to the the Address of the President of the Republic of Kazakhstan N.A. Nazarbayev to the people of Kazakhstan of 2018 the task "to ensure the efficiency of the labor market, create conditions that everyone can realize their potential" is set [1]. Among the many ways to solve this problem are the modernization of the public consciousness and the reform of the consciousness of each member of society. "Public consciousness also includes legal awareness, which is an element of legal culture. Therefore, the successful modernization of public consciousness requires the development of measures and specific projects aimed at raising the level of legal awareness and legal culture of all subjects, both state and civil society institutions and citizens" [2]. The Rukhani Jangiru program initiated by the President of Kazakhstan is directed to modernization of consciousness of all Kazakhstan society and all citizens of RK. This reforming concerns all components of public consciousness and is directed including to problems of fixing, providing and protection of the rights and freedoms of citizens of RK.

That part of the legal consciousness of society, which is addressed to the constitutional sphere of regulation, performs the functions of ensuring the normal functioning of basic human rights. This is due to the fact that the constitutional sector of the legal consciousness of society ensures the demonstration of the role and place of human rights both in the life of the latter and in the development of society as a whole, provides an epistemological explanation for the process of their formation, improvement and implementation, reveals the forms of their constitutional mediation, support and creation of favorable conditions for implementation, prepares public opinion for reforms and reforms in the field of human rights, promotes an understanding of each priority given direction of the state.

By mediating the legal phenomena of public life, including the processes of formation, development and implementation of human rights, the constitutional part of the sense of justice seeks to consider them from the standpoint of constitutionalism as a whole. It comprehends and evaluates them from the point of view of constitutional fixing, regulation and protection, "tries on" them the established constitutional technologies, procedures and mechanisms. And the consequences of the impact of different components of 
constitutionalism on the formation, development, functioning and protection of human rights (the constitutional part of the sense of justice) it also assesses the standards of constitutional institutions, structures and relations.

In other words, without a conscious component (that is, without a constitutional part of the sense of justice), the entire system of constitutionalism, its potential and the possibilities of action can't at least somehow manifest itself outside, unable to lead to the intended consequences of human rights. Now the significance of this conscious component of constitutionalism is growing even more. Therefore, it is wrong to underestimate him, not to touch or reveal the mechanisms for manifesting his role, not to cover the forms, methods and consequences of his actions.

Practice shows that the mechanisms of functioning of the sense of justice within the framework of constitutionalism are diverse and effective. They complement the operation of all other legal mechanisms and in combination with them; improve the effectiveness of the realization of the rights and freedoms of citizens.

In the article we will mainly deal with that part of the sense of justice that covers the sphere of constitutional law and mediates the functioning of human rights.

Concerning the structure of the constitutional part of the sense of justice, it seems that they should proceed from the fact that, like the legal conscience as a whole, it consists of components of an ideological and socio-psychological nature. Refracting this position to the constitutional sphere of the life of society and filling it with content that is inherent in this sphere, we can state that it should be a question of constitutional ideology and constitutional and legal psychology. They, mutually complementing each other and being in the relations of all-round interaction, eventually form a certain unity and integrity within the framework of the system of constitutionalism.

This interpretation of the structure of legal consciousness was generally established in jurisprudence by the efforts of I.E. Farber [3] and his followers. It was and goes about the division of legal consciousness into such structural elements as legal ideology and social and legal psychology. The legal ideology was conceived and the majority of jurists continue to be thought of a set of legal views, ideas, judgments that express the essence and content of law, its purpose in the life of society, the forms of its impact on the most important social relations. The peculiarity of the legal ideology is that the views, concepts that form it mutually complement each other, do not contradict each other form a coherent unity and integrity. Socio-legal psychology, unlike legal ideology, appears as a set of spontaneously arising views, perceptions and views on the law, often inconsistent with each other and sometimes coming into direct contradiction between themselves; In addition, the socio-legal psychology includes a sensual and emotional component of the sense of justice, which includes a set of experiences, feelings, emotions that have a legal color and legal content.

At the present time, an attempt has been made to give a somewhat different concept of the structure of legal consciousness: in the opinion of A.V. Polyakov, its structural constituents are legal ontology, legal axiology, legal phraseology [4, page 397]. "The main types of relations of consciousness to the world are cognition, value relationships and practice. Accordingly, in the legal consciousness, it is possible to distinguish cognitive, value-oriented and communicative-volitional elements from which both individual and public legal consciousness develops" [4, page 397]. In the above interpretation, legal ideology and legal psychology as structural parts of legal consciousness are not discarded or excluded, but are included as components of legal axiology [4, page 398].

Differentiating legal awareness on the part taken in the sectoral cut (constitutional, administrative, environmental and some other parts of legal awareness), we try to consider them as relatively independent units of legal consciousness, which possess both features and attributes inherent in the whole legal conscience in general, and are characterized by features, inherent only to them. If the sense of justice as a whole mediates the whole set of human rights, the constitutional part of the sense of justice does not set itself such a broad goal: it seeks to mediate in detail fundamental rights and freedoms.

Of course, this also can't be limited to, since it serves the leading branch of law - constitutional law, and therefore it can't fail to provide guidance on the general laws governing the regulation of all human rights. For example, it advocates that the consolidation, regulation and protection of human rights are given priority in all republican legislation.

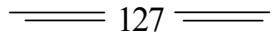


Success in the functioning of the constitutional part of the sense of justice depends largely on how synchronously the components of its structure operate.

Practice shows that not every system of constitutional and legal psychology actively interacts with this type of constitutional ideology, and, conversely, not every kind of constitutional ideology finds a positive response, approval by this system of constitutional and legal psychology. As a rule, a close interaction of the above components of the constitutional part of the sense of justice is observed when they (the named components) are close to each other in character, direction, defended goals and objectives.

In other words, it is necessary fully to take into account the features of the systems of constitutional ideology entering into interaction and constitutional-legal psychology. In the scientific literature, attempts have been made to classify them according to different criteria. According to the classification of A.V. Polyakov, those types of legal ideology that derive the right from human values, can be attributed to the anthropocentric (individualistic) type of ideology, those types in which the dominant value and the source of law is recognized by God, refer to the theocentric ideologies, and when the legal values recognize the rights of groups, classes, nations - these are socio-centrist (or collectivist) ideologies [4, page 399]. Other classifications of ideologies (including constitutional ones) are also being substantiated and substantiated. Each type of constitutional and legal psychology tends, of course, not to everyone, but only to those ideologies that are close to it in spirit. In turn, each kind of constitutional ideology seeks to focus primarily on interaction with a homogeneous (one-type) system of constitutional and legal psychology with it.

Unlike constitutional ideologies, the types of constitutional and legal psychology are more amorphous. They are less slender and applied to them the gradation of internal units are not as obvious and noticeable as in constitutional ideologies. And, nevertheless, the constitutional and legal psychology of pensioners differs markedly from the constitutional and legal psychology of the representatives of the middle class of owners, just as constitutional and legal psychology of workers is little like the constitutional legal psychology of, say, state employees, peasants, etc..

Human rights as objects of the functioning of constitutional consciousness pass in the aspect of their genesis and development two stages - a stage of reflection in consciousness and a stage of working out ways of legal influence on them with the purpose of their consolidation, improvement and development. At the first stage, human rights are reflected in the constitutional consciousness, resulting in the formation in it of a whole set of relevant legal views, views, views, concepts relating to the reflected human rights. The latter are the equivalent of real human rights.

In due time K. Marx and F. Engels wrote in "The German ideology": "Consciousness (dasBewußtsein) can never be something other as conscious life (dasbewußteSein) and life of people is real process of their life. If in all ideology people and their relations turn out to be put on their heads, as if in a camera obscure, then this phenomenon also flows from the historical process of their life, just as the reverse image of objects on the retina results from the immediate physical process of their life ... » $[5$, page 25].

At the same time, the parallels between the real human rights, on the one hand, and the ideas about them that form in the mind, on the other, are largely conditional. To substantiate and comment on this provision, we again refer to the words of K. Marx from his letter to F. Lassalle dated July 22, 1861: "The legal representation inherent in certain property relations, although it grows from them, on the other hand, does not coincide and can't coincide with them" [6, page 504].

Identifying the reasons for this discrepancy between the legal representation of property and the property relations themselves, we must specifically point out that the first of them (legal representation of property) is not reduced only to the reflection of existing property relations, but also contains an indication of the way in which they have legal effect on them the purpose of giving them the right state. In other words, in this example, the second stage of the genesis of human rights is boldly delineated - the stage of working out ways of legal influence on them with a view to their consolidation and development in the required direction.

At the same time, the results of the functioning of public consciousness at the first stage serve as the basis for its functioning in the second stage, although the focus of legal thought here is essentially changing, for instead of simply reproducing what actually exists, what human rights should really be. Therefore, in the structure of the mental expression of the processes by which the human rights situation is 
mediated, the role of components associated with state wolfing increases, when the focus is on ensuring what the state desires in this sphere of relations.

What has been said makes the task of ensuring that the whole process of legal education acts clearly, smoothly and effectively. And this is possible only when all the initial, intermediate, subsequent stages will work at the proper level and when, consequently, the final result of the whole process of law formation will turn out to be qualitative and will not be burdened with errors, miscalculations (at least the latter will be on order is less or they will not be so serious).

The characteristic of the constitutional consciousness will benefit from the use of materials of concrete sociological research in various spheres of constitutional regulation. Association "Interlegal" on the basis of a broad survey of citizens in leading regions of Kazakhstan conducted a survey of the causes of corruption in society. The poll allowed touching on the nature of corruption manifestations in the economy, socio-political and cultural-ideological areas of relations, to dwell on the circumstances that determine the prevalence of these offenses, to show the relationship between the level of consciousness of the population and the state of order in the country. The survey indicates the need to use the potential of consciousness in such a way that the benefits from it affect the functioning of all components of constitutionalism [7, page 328].

Specifically, sociological research makes it possible to overcome or at least reduce the abstractness of the presentation of problems of constitutional consciousness, to reinforce theoretical positions and conclusions with quantitative indicators from certain spheres of social relations, and to strengthen their arguments and justification. Significantly, by complicating the subject and subject matter of concrete sociological research, S.M. Zlotnikov received a different angle of perception of relations related to corruption: the latter was traced to him in the aspect of the impact of illegal migration on it, so that the role of consciousness turned out to be illuminated in other aspects [7, page 328].

The constitutional part of the sense of justice can't give priority to human rights. True, it was not always so; For a long time they (that is, human rights) did not belong to the number of important objects of legal conscience and were even considered inseparable from the state's activity in the establishment and protection of law and order and the rule of law. But the objective significance of human rights gradually began to make itself felt, forcing the constitutional part of the sense of justice to change attitudes toward oneself. Step by step, it begins to approach the view that in the activities of the state, human rights can't be regarded as a secondary object, but a key area of concern. At the present stage of development, the constitutional part of the sense of justice stops at the fact that securing, securing, guaranteeing human rights, protecting them and facilitating their full implementation become the main function of a liberaldemocratic state [8, pages 114-115]. Therefore, in the functioning of the most constitutional part of the legal conscience, the justification for the need to uphold human rights, to prevent them from ignoring and violating one of the leading positions.

As is known, the leading component of the legal consciousness of society is the legal ideology, that is, the part that provides the theoretical level of reflection of legal reality, gives it a theoretical evaluation and justification, and, penetrating deeper into the real life processes, is able to approach the correct reproduction of laws and tendencies of legal development $[3 ; 9 ; 10]$. Similarly, it is possible to imagine the correlation of the components of constitutional consciousness, among which the leading ideology, no doubt, is the constitutional one. It pretends to the role of scientific and theoretical reflection of the constitutional realities of society, strives to ensure a correct representation not only of the superficial, but also of the underlying laws and trends in the formation and development of constitutional relations, structures and institutions. And in the system of constitutionalism, it refers to the number of determining and main links, whose direct or indirect influence is experienced by all other links. Constitutional ideology observes everything that is mediated by the remaining links of constitutionalism, keeps all constitutional and legal phenomena in its field of attention, and therefore the scope of its vital processes is great. It includes the basic human rights and freedoms.

The functions of constitutional ideology, addressed to human rights and freedoms, are diverse, including the demonstration of their role and place both in human life and in the development of society as a whole, the gnosiological explanation of the process of their formation, improvement and implementation, analysis, evaluation and justification of each right and each freedom, ensuring their 
support in public opinion, developing measures to secure them in the Basic Law of the state and other acts of constitutional law. Equally important are the functions of the constitutional ideology to identify the stage and stage of the process of the realization of human rights and freedoms, to ensure the synchronization of the operation of the normative and individual forms of their implementation, and to demonstrate the need for public opinion on the priority of this direction of the state.

For a long time, human rights were not perceived by the mind as an important direction of the state's activity. On the contrary, their meaning was downplayed in every possible way. In the nomenclature of social values, they were placed on one of the last places, giving way to military-aggressive and militarydefensive affairs, the general interests of the state, the management of certain branches of economic, socio-political, cultural construction, external relations, etc. It was believed that human rights do not have independent significance are derived from other matters and do not deserve serious attention. They were interpreted as a result of the subjective discretion of the state, which allegedly could deprive people of certain rights, or, on the contrary, endow them with them, etc.

A fundamental revolution in the evaluation of human rights, in characterizing their value, significance and role in the life of man and society, in the means of their realization is the result of the activity of consciousness (political, moral, legal, including the latter's offshoot, as constitutional). Under the influence of profound socioeconomic and political changes in the life of society, the strengthening of the processes of democratization and the humanization of all its spheres, public consciousness began to carry out a frontal reassessment of values, gradually bringing to the forefront what is directly related to man, his life, health, well-being, interests and needs, and pushing to the middle and back plan that concerns the activities of the state not in the most fateful and non-core spheres of government. And now the scale of social values in the state has changed radically and significantly. The accents in the state's policy have not become quite the same as they were a century or even half a century ago. An important role in achieving this was played by the public conscience, including the constitutional consciousness and its leading part the constitutional ideology. It (the role of constitutional consciousness and constitutional ideology in recognizing the priority role of human rights) is truly fateful and even revolutionary. As a result, human rights have "played up" in a new way, have acquired a profound sound, have lost their former obscure, faded, derivative meaning of state affairs, have begun to play a role that no other, including many state.

As we see, the component of constitutionalism, which is far from or relatively far from the regulatory functions of constitutional law, has made an invaluable contribution to the reassessment of the place, role and significance of human rights in the general mechanism of legal regulatory and individual regulation. That is, not only purely regulative, but also other (ideological, organizational) components of the system of constitutionalism have their own influence on securing, guaranteeing, securing, protecting and implementing human rights and freedoms. Therefore, the consideration of the role of constitutionalism as a whole, and not only purely regulative components of constitutional law, in the functioning of human rights enriches the palette of research tools, allowing not to miss some important details of this multivalued process, more accurately to evaluate all its links, stages and stages, to embrace it wholeheartedly , is complex.

Of course, to the above, the role of the constitutional sector of the legal conscience of society in the work of human rights and freedoms is not reducible. In life, it is more diverse and covers different cases related to certain aspects of the process of the exercise of human rights and freedoms. Let's dwell on some of them.

In connection with the growing role of human rights and freedoms, there is a need to mobilize the public to initiate the development of new constitutional ideas in terms of rights and freedoms and to seek support from their people. In this particular case, we are talking about actions at the regulatory level, because we must raise the issue of new rights (or about innovations in previous rights) that should be constitutionally consolidated. Here the role of constitutional consciousness (constitutional ideology) is reduced to forming a basis for working out proposals on the adoption of a new act on rights and freedoms or changing previous acts, drafting bills and obtaining their consideration.

In other cases, actions of a constitutional and ideological nature are directly aimed at stabilizing the norms of the Basic Law of the state and preventing any significant changes in its content. When representatives of some political forces of the country, as well as certain segments of the population, 
demanded the introduction of urgent (from their point of view) changes in the Constitution of the Republic of Kazakhstan, including its norms on human rights and freedoms, a group of doctors and professors of law addressed the leadership and the public the country in which it was argued that the potential of the current Constitution of the Republic of Kazakhstan had not yet been exhausted and that changes, additions and amendments to it were inexpedient. The President of Kazakhstan responded to this appeal and supported his idea. This for several years "frozen" the Constitution of the Republic of Kazakhstan in its previous form, but could not stop the constitutional development in general: after a while, a discussion began on the directions of the constitutional reform, which resulted in the introduction of a number of changes and additions to the Basic Law, including its norms on the rights and freedoms of man (May 2007).

This example shows that the deterrent effect of the constitutional ideology on the development of the norms of the Basic Law on Human Rights and Freedoms is inferior to its impact on the modification and updating of these norms. Thus, there is a desire to ensure the dynamic state of the constitutional regulation of human rights and freedoms, its prevalence over the desire to approve the static state (i.e., immutability) of legislation on these issues.

Let us cite one more argument in favor of recognizing the predominant direction of the influence of the constitutional ideology on legislation, which is oriented toward its dynamic development, and not to a static, unchanging state. It means that the constitutional ideology not only reflects the current state of constitutional institutions, structures and relations in the country, but also gives predictive views about their future, as it were, "peeks" in their perspective. These ideas often serve as the basis for preparing for constitutional reforms and reforms, and in some cases act as a kind of "building material" for them.

Constitutional ideology affects the development and evolution of not only the basic constitutional rights and freedoms of man, but also develops a common strategy and tactics for the development of all human rights and freedoms. At the same time, if the basic human rights and freedoms find a comprehensive justification, interpretation, explanation and argumentation in the constitutional ideology (up to details, particulars, individual nuances), the remaining human rights and freedoms (sectoral, relating to individual spheres of human life) are addressed in the constitutional ideology in general terms, without detail and concretization. The latter (i.e., detailing and specification) is given by the relevant branches, sub-sectors and institutions of law, the subject of which are these rights and freedoms.

It should be said about the great influence of the constitutional ideology on the pace of development of legislation on human rights and freedoms. By concentrating the most important ideas about society, the state, societies and personalities, the constitutional ideology can express reasoned judgments about the timing and sequence of the adoption of normative legal acts, including acts on human rights and freedoms. She can recommend one of these acts to be adopted in a primary, accelerated order, and with others while to wait, wait. With regard to the content of such acts, it will be given more details of its recommendations on acts on fundamental human rights and freedoms, while the contents of acts on other human rights and freedoms will only be dealt with in general terms, without detailed elaboration and concretization.

For example, the constitutional ideology expresses only a general opinion on the necessity of refraining from the use of the death penalty for the commission of the majority of crimes (or, conversely, the preservation of this means of influencing the perpetrators of many criminal acts). At the same time, she justifies her position with arguments stemming from the widest possible analysis of the needs of social development, comparing human interests with those of individuals. With regard to the detailed consideration of the death penalty in comparison with other measures of criminal punishment, the correlation of their results and consequences with the tasks facing the state, society, societies, a detailed analysis of the personality of the perpetrator, the specifics of each crime, and so on included in the duties of the criminal-legal (criminal-procedural, criminological) ideology. The possibilities of constitutional ideology in this part are limited and the totality of the means used by it is insufficient.

When considering the impact of the constitutional ideology on the development of human rights and freedoms, one can't abstract from its characteristics, consisting in the fact that it is a collection (or system) of views, views, ideas, ideas that form an internally coherent, almost consistent integrity and unity. All these components of the constitutional ideology act in unison, as if they "hit the same point", mutually 
complement each other, pursuing the same goals and objectives. In literature, there was even a sign of the conceptuality of each ideology, by which it means that it (ideology) proceeds from one concept, is permeated from beginning to end by it.

It's true, that in every society, not one but several types of constitutional ideology are formed, and each of them defends its value system, solves its goals and tasks, differing (sometimes significantly) from the goals and tasks of other types of constitutional ideology. You can talk about the constitutional ideology of the middle class of owner-entrepreneurs, the ideology of workers, peasants, and intellectuals. All of them openly or secretly struggle with each other; they strive to enforce their attitudes, to translate their views and views on human rights and freedoms in the norms of constitutional law. During the elections to the bodies of state power and local self-government, each type of constitutional ideology develops the strategy and tactics of those social strata and groups whose interests it represents. At the same time, the meaning of participation in elections is seen in achieving a common victory and obtaining the majority of seats in elected bodies, or, if not achieve a common victory, then at least hold representatives (the more, the better) in elected bodies, or, finally, simply to propagate their position and to criticize the position of the remaining forces and groups participating in the elections. But it is of particular importance that each party participating in the elections develops its electoral platform and an expanded program, which it plans to implement both in case of victory and any other election outcome. Unfortunately, in this case, Kazakhstan is taking only the first steps and is going through the initial period of the formation of constitutional views and notions, not to mention the formed versions of the constitutional ideology. There is a lot of duplication in the programs of the parties, there are no clear, established formulas and conclusions, the constitutional goals of different social strata and groupings differ little from each other. Only with the accumulation of experience of participation in solving constitutional problems by society as a whole, and by each social group, these shortcomings will gradually become obsolete.

It should be noted that ideology in general, we sometimes idealized the constitutional ideology, unilaterally exaggerating its advantages and advantages. It was believed that ideology, providing a theoretical reflection of reality, creates the precondition for the achievement of truth. But for some reason we ignored Engels' words about the perverse nature of any ideology, for, by setting forth class goals and tasks, it produced a fit for theoretical views and conclusions. According to F. Engels, ideology is the deduction of reality not from itself, but from representation [11, page 93]. Therefore, it turned out that the tasks and goals of a particular society were extrapolated to the whole of society, which led to a shift in conclusions and perceptions. Exactly the same advantages of constitutional ideology were exaggerated, stemming from the theoretical nature of the reflection of life processes and relations in it.

Nevertheless, the constitutional ideology can approach the truth if it rises above the interests of a single society, tries to reach the general social level of cognition and reflection of reality. The more in this type of constitutional ideology elements of general social importance, so it is able to ensure the development of measures in the interests of the whole society.

As it is noted in all Messages of the President of the Republic of Kazakhstan to the people of Kazakhstan, the constant improvement of the social well-being of Kazakhstanis, all strata and social groups of the Kazakh society is and will remain in the forefront of state policy [12]. In carrying out this task, ideology, including constitutional, should occupy one of the central places.

The transition of Kazakhstan society from the totalitarian conception of society and the state and its relationship with the individual to civilization values, the design in Kazakhstan of a classical, liberal type of civil society, the attempt to transfer to the autonomization of the individual implies the nomination of constitutionalism as a national idea. The assertion of constitutionalism as an integrative national idea and as a component of a nation-wide ideology is of particular relevance in modern Kazakhstan, when the process of determining universally valid value and ideological landmarks is underway [13, page 7].

As a special component of constitutional public consciousness, constitutional and legal psychology includes, firstly, a wide range of spontaneously developing, non-systematized constitutional views, ideas, judgments and ideas that differ from views, ideas, judgments and ideas that form in their totality a constitutional ideology; secondly, a diverse layer of emotions, feelings, emotions, mindset, formed in 
people in connection with the formation, functioning and development of constitutional institutions, structures and relationships. Being so heterogeneous, heterogeneous education, in which ideas and feelings, views and moods, ideas and emotions are intertwined, constitutional and legal psychology from the environment in which the authority, power and significance are formed, acquire, change and develop constitutional norms and institutions. The latter in their impact on public life are mediated both by constitutional ideology and constitutional-legal psychology. At the same time, they mutually influence each other: constitutional norms and institutions, as well as the forms of their implementation and implementation, influence the development of constitutional consciousness; in turn, the role of the latter can't but affect the real state of all means of constitutional regulation.

In the scientific literature, the issue of socio-legal psychology is highlighted mainly in the sense that it is an integral part of the sense of justice and is characterized by a certain system of relationships with legal ideology. As for the socio-legal constitutional psychology as a component of the system of constitutionalism and the consequent role of it in relation to those functions that face constitutionalism in general and each of its components separately, this task has not yet found in science its detailed disclosure and lighting. Meanwhile, the analysis of social and legal constitutional psychology in comparison with all links of the system of constitutionalism expands the "review sector", allows to include in the sphere of attention of researchers such spheres of its action that, under the former approach, were either at the periphery of the study or not at all. The differences between these two aspects of the study of socio-legal constitutional psychology can be demonstrated by the example of its influence on the state of human rights and freedoms. In the first case (namely, when studying social and legal constitutional psychology as an integral part of constitutional consciousness), it is a question of the fact that human rights and freedoms are the object of reflection in consciousness, that they are reproduced in it (in consciousness) in an adequate or in perverted form.

Constitutional legal psychology takes its place in the structure of constitutionalism and, it must be said, that its influence is felt at different "floors" and levels of constitutionalism.

It is possible to note the following most significant differences between socio-legal constitutional psychology and constitutional ideology. If social and legal constitutional psychology is based on empirical reflection of constitutional reality, the constitutional ideology tries to provide a theoretical reflection of this reality. Therefore, the concepts and categories of socio-legal constitutional psychology are inferior to the concepts and categories of constitutional ideology in terms of the depth of penetration into the essence of the reflected phenomena, as well as the quality of reproduction in them of the properties and attributes of the latter.

The presence of a single object of reflection in socio-legal psychology and constitutional ideology to some extent brings together and brings together these two components of constitutional and legal consciousness. But you can't put a sign of identity between them. The same social relations (not all, but only those that are among the main ones that determine the basis of the socioeconomic system and political organization that affect the status of the individual, the structure and activities of the state mechanism) are reflected in the constitutional socio-legal psychology and constitutional ideology, but the latter can not reflect them in the same way, because their approaches to the named relations, the mechanisms of their perception, analysis and cognition are completely different. Hence, the results of reflecting the constitutional-legal reality in them can't be put on one level. Constitutional legal psychology, in the process of reflecting its sector of reality, willingly or unwittingly emphasizes its external connections and mediations, is unable to penetrate its deep layers, for its inherent empirical level of reflection of reality does not allow it to do so. There is much more scope for penetrating the reality reflected in constitutional ideology, which has a theoretical form of reflection in its arsenal. Using it, the constitutional ideology is not limited to the reproduction and knowledge of what lies on the surface of the constitutional relations reflected by it, but tries to reveal, reveal and analyze the inherent laws and tendencies of development, which, as a rule, is inaccessible (or little available) to constitutional legal psychology .

Such differences in the reflective activity of constitutional ideology and constitutional and legal psychology affect the quality of the means of influence of constitutional law on the processes of society's

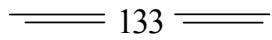


life developed by the above-named parts of the constitutional legal consciousness. "The measures proposed by the legal psychology are much inferior in quality to the legal measures being developed by ideology" [10, page 94].

The view from the constitutional and psychological positions on the solution of the problems of securing, securing and protecting the rights of citizens and especially their considerable expansion is often superficial, unreasonably maximalist, without taking into account the fact that there are sufficient material, economic, resource, organizational and technical and other conditions for stating the issue of fixing these innovations in legislative and other normative legal acts, or they are absent. The main thing is that there is no confidence in the guaranteed implementation of such requirements with regard to the empowerment of citizens. Sometimes, at the constitutional and psychological level, the main attention is paid to the promotion of demands for the expansion of the rights of citizens, but many of them eventually turn out to be declarative, impracticable because the state and society lack the necessary resources for their implementation.

This is the "Achilles' heel", i.e. the most vulnerable place of many demands put forward by the constitutional and psychological part of the legal consciousness of society, of certain social groups, of individual citizens. For example, the requirements for increasing the amount of pensions directly depend on the material situation of the country, the size of the revenue side of the state budget, and a multitude of economic and socio-political indicators. And if you do not observe the sense of proportion and do not show a sober and even critical approach in these matters, the overstated demands for a serious increase in pensions become ephemeral, and if put "to perform" can lead the country into a difficult situation.

The question of the requirements for citizens' rights, put forward by constitutional ideology, is raised a little differently. Based on the theoretical reflection of reality, it is much more balanced approach to the formulation of its requirements, which are to be fixed in legislative and other normative legal acts, strives to ensure that they (the demands put forward by it) fully correspond to those material, economic, sociopolitical, technical and other conditions that have developed in the society in this period. In contrast to the constitutional and psychological component of a society's legal conscience, the constitutional ideology, in developing its recommendations, proposals and demands, tries to avoid judgments and ideas based on the reflection of only the superficial aspects of constitutional reality and taking into account accidental secondary factors, makes efforts to base its proposals and requirements were put theoretical, relevant (or close to) the truth of the idea of the basic laws and trends of development I am the constitutional sphere of the life of society and the state. Therefore, there is not such a big gap in the proposals and demands on the issue of citizens' rights developed by the constitutional ideology and the actual needs of social development, which is typical for the proposals and demands put forth by the constitutional and psychological part of the sense of justice.

Important differences between the constitutional ideology, on the one hand, and the constitutional and psychological part of the sense of justice, on the other, are found when comparing the inherent processes of mobility, dynamism, and variability. These processes are ambiguous and depend on various causes, for example, depending on which stage of changes (initial, subsequent) we are talking about. The initial period of changes may occur earlier in different structural subdivisions of the constitutional and legal consciousness: in some cases before in the constitutional-psychological part of consciousness, in others earlier in the constitutional ideology, and sometimes simultaneously in both parts of the constitutional consciousness. But the subsequent spread of the change occurs more quickly within the framework of the constitutional ideology, whereas in the sphere of the constitutional-psychological part of the legal consciousness, changes cover it much more slowly, meeting resistance from its other stable and stable components. For some time (sometimes long) new ideas, views and opinions on the rights of citizens coexist with the previously arisen and already established ideas, views and judgments. But the latter, with the advent of the former, do not by themselves disappear, but try to prove their rightness, necessity and usefulness. Such a confrontation between the new and the old in the content of the constitutional and psychological part of the sense of justice lasts much longer than in the content of the constitutional ideology. In the latest active actions of ideological theorists, the process of achieving the superiority of the new over the old is accelerating, which is facilitated by the unity, integrity, harmony, consistency, complexity of constitutional ideology as a structural unit of constitutional and legal consciousness. 
From what has been said, we can conclude that, in the words of K.S. Birzhanova, "the reflection of reality is realized not only in legal ideology, but also in legal psychology, with the participation of which the human action is anticipated and given it a purposeful character" [14, page 266]. The significance of these structural divisions of the constitutional legal consciousness is that each of them not only fulfills the goals and tasks assigned to it in the part of promoting the establishment, guaranteeing, protection and realization of human rights and freedoms, but also tries to supplement what is being done by the other of them. In such interaction - the keystone to the success of constitutional consciousness as an important part of the system of constitutionalism.

"The updated Constitution is the driver of the further progressive evolution of Kazakhstan on an ascending one. The Basic Law as a system of constitutional coordinates, within which legislation is adopted, society develops and state bodies work, at the current stage meets the interests of the country's development and contains sufficient potential to ensure the sustainability of the course" [15]. Constitutional legal consciousness based on the renewed constitution, all its structural units contribute to the protection and maintenance of human and civil rights and freedoms.

\section{REFERENCES}

[1] N.A. Nazarbayev. Message of the President of the Republic of Kazakhstan to the people of Kazakhstan "New opportunities for development in the conditions of the fourth industrial revolution" // Kazakhstanskaya pravda. 2018, January 10. №6 (28635).

[2] K.A. Mami. The implementation of constitutional novels is the key to further prosperity of Kazakhstan // Kazakhstanskaya pravda. 2018, 12 March. № 28 (28653).

[3] Farber I.E. Legal awareness as a form of public consciousness. Moscow: Juridical Literature, 1963. 218 p.

[4] Polyakov A.V. General theory of law: problems of interpretation in the context of a communicative approach. Textbook. - St. Petersburg: Publishing House of St. Petersburg State University, 2004. P. 397-399.

[5] Marx K., Engels F. Compositions.- Moscow: St. publishing house of political literature, 1956. T.3. P. 25.

[6] Marx K., Engels F. Works. -M .: St. publishing house of political literature, 1959. T.30. P. 504.

[7] Zlotnikov S.M. Corruption and illegal migration // In: The fundamentals of counteraction to corruption. Tutorial. Almaty: PF "Transparency Kazakhstan”, OFFUIC "Interlegal” in Kazakhstan, 2004. P. 328.

[8] Functions of the state in the conditions of the modern world (on the materials of independent Kazakhstan / Edited by M.T. Baymakhanov, Almaty: KazGUU Publishing House, 2005. P. 114-125.

[9] Ostroumov G.S. Legal awareness of reality. Moscow: Nauka, 1969. P. 102-102.

[10]Baymakhanov M.T. Contradictions in the development of the legal superstructure under socialism. Alma-Ata: Nauka, 1972. P.94.

[11]Engels F. Anti-Duhring. Moscow: Politizdat, 1983. p. 93.

[12]See: Message of the President of the Republic of Kazakhstan to the people of Kazakhstan 2005-2018.

[13]Amandykova S.K. Formation of the doctrine of constitutionalism in Kazakhstan. - Karaganda, 2002. 439 p.

[14]Birzhanova K.S. Legal consciousness // Theory of state and law. Textbook for higher educational institutions / Ed. A.U. Beisenova. Almaty: Atamura, 2006. P. 266.

[15]Message of the Constitutional Council of the Republic of Kazakhstan "On the state of constitutional legality in the Republic of Kazakhstan" (Announced at a joint meeting of the Chambers of the Parliament of the Republic of Kazakhstan on June 15, 2018) // Kazakhstanskaya Pravda. 2018, on 18 July. No. 112 (28741)

\section{Д.М. Баймаханова, Д.А. Оспанова}

Әл-Фараби атындағы Қазақ ұлттық университеті, Алматы қ.

\section{КОНСТИТУЦИЯЛЫҚ-ҚҰҚЫҚТЫҚ САНА - КОНСТИТУЦИОНАЛИЗМНІН МАНЫЗДЫ КОМПОНЕНТІ РЕТІНДЕ ЖӘНЕ ОНЫҢ АДАМ ҚҰҚЫҚТАРЫ МӘСЕЛЕЛЕРІН ШЕШУДЕГІ РӨЛІ}

Аннотация: Аталмыш мақала қоғамның құқықтық санасының конституциялық саласын ретке келтіруші және адамның негізгі құқықтарының қызметін қамтамасыз ететін негізгі қызметтің жүзеге асырылуын қамтамасыз ететін бөлшегін зерттеуге арналған. Ол әділетті қоғамның конституциялық секторының өміріндегі рөлі мен адам құқықтарын орынды қамтамасыз етуге көмектеседі және тұтастай қоғамның дамуына, олардың қалыптасуы, дамуы және жүзеге асыру үрдісіне гносеологиялық түсініктеме береді, олардың конституциялық медиация пішінін ашады, қолдау және қолайлы жағдай жасау қағидасын іске асыру 
үшін жағдай жасау, адам құқықтары саласындағы реформа және қайта қоғамдық пікір дайындау мен берілген әрбір басымдық түсінуге ықпал етуші мемлекет бағыты.

Түйін сөздер: Конституция, конституционализм, конституциялық-құқықтық сана, конституциялық идеология, конституциялық психология, адам құқықтары мен бостандықтары, Қазақстан Республикасы азаматының құқықтары мен бостандықтары.

УДК 342.7(574)

\section{Д.М. Баймаханова, Д.А. Оспанова}

Казахский Национальный университет имени аль-Фараби, г.Алматы

\section{КОНСТИТУЦИОННО-ПРАВОВОЕ СОЗНАНИЕ КАК ВАЖНЫЙ КОМПОНЕНТ КОНСТИТУЦИОНАЛИЗМА И ЕГО РОЛЬ В РЕШЕНИИ ПРОБЛЕМ ПРАВ ЧЕЛОВЕКА}

Аннотация: статья посвящена исследованию той части правосознания общества, которая обращена к конституционной сфере регулирования, выполняет функции по обеспечению нормального функционирования основных прав человека. Это обусловлено тем, что конституционный сектор правосознания общества обеспечивает показ роли и места прав человека как в жизнедеятельности последнего, так и в развитии общества в целом, дает гносеологическое объяснение процессу их становления, совершенствования и осуществления, раскрывает формы их конституционного опосредования, поддержки и создания благоприятных условий для реализации, подготавливает общественное мнение к проведению реформ и преобразований в сфере прав человека, способствует пониманию каждым приоритетности данного направления деятельности государства.

Ключевые слова:Конституция, конституционализм, конституционно-правовое сознание, конституционная идеология, конституционная психология, права и свободы человека, права и свободы гражданина Республики Казахстан.

Сведения об авторах:

Baimakhanova D.M. - doctor of law, professor of chair of the theory and history of state and law, constitutional and administrative law, law department, al-Farabi Kazakh National University, Republic of Kazakhstan, Almaty, E-mail: dina_405@mail.ru; https://orcid.org/0000-0002-2741-4348;

Ospanova D.A. - candidate of law, associate professor of chair of the theory and history of state and law, constitutional and administrative law, law department, al-Farabi Kazakh National University, Republic of Kazakhstan, Almaty, E-mail: azizkhan_0606@mail.ru, https://orcid.org/0000-0001-7561-6596 


\section{МАЗМҰНЫ}

Алтыбаева С.М., Савындыков Е.С. Көркем мәтін құрылымындағы мифопоэтикалық модельдеу және мәдени код...... 5 Сембиева Л.М., Мажитов Д.М., Карпиикая М.Е., Хамитова Д.М. Экономиканы жаңғырту жағдайындағы ЕАЭО елдерінің монетарлық жүесінін өзгеруі .....

Құлсариева А.Т., Султанова М.Э., Шайгозова Ж.Н. Фольклор және сәйкестілік: Қазақстанның қазіргі заманғы

мәдениетіндегі тарих, жады және аңыз шығармашылығы ........................................................................................... 19

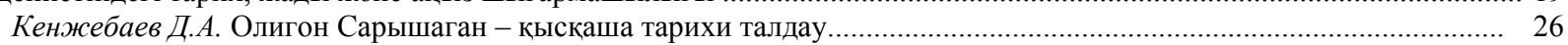

АбдулинаГ.А., БазарбаевА.Г. Ұйымдардағы адам ресурстарын басқарудың заманауи тұжырымдамалары................ 33

Авыбаев А.Н., Адибаева А.К. Геноцид туралы БҰҰ Конвенциясының қатысушы мемлекеттердің қылмыстық

заңнамаларындағы имплементациялық тетіктері: жалпы салыстырмалы талдау............................................................ 39

Ахметжанов Б., Тәжібекова К.Б., Шаметова А.А. Қазақстан көлік өнеркәсіптің дамуын талдау............................. 44

Аюпова 3.К., Құсайынов Д.Ө. Тәуелсіздік жағдайындағы қазақстан республикасының конституциялық-құқықтық

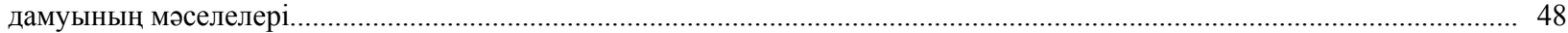

Нурпеисова А.А., Рей И.Ю., Бижанов Д.Т., Тлеужанова Д.А. Инновациялық өндірісді жасаудың процесін

бақылауының негізгі элементтері

Гиздатов Г.Г. Қазақстандық дискурсының құрылымы психолингвистиякалық зерттеу .

Ищанова Р.К. Мемлекеттік шығындарды басқару - мемлекеттің қаржылық тұрақтылығын қамтамасыз ету.............. 64

Мадышева А.М. Бикенова А.С., Елеусиз Л.Т. Білім саласындағы туристік қызметтер............................................. 68

Ескалиева А. Ж., Баймуханова М.Т., Ахмурзина Д.О. Әлеуметтік сала адам капиталының сапасын қолдаудың

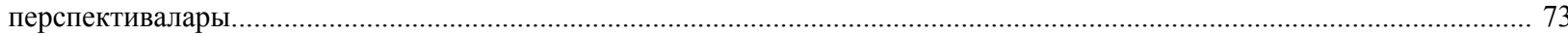

Мархаева Б.А., Козбахова Д.Л. Жауапкершілік орталық және трансферттік баға белгілеу............................................ 79

Сабирова Р.К., Утепкалиева К.М., Кабаков С.Б. Қазақстандағы ауыл шаруашылығы экономикасының

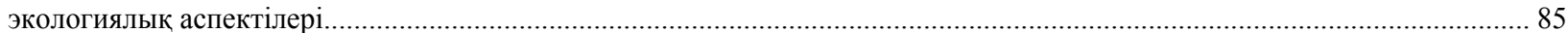

Тлесова Э., Хойч А., Кураш Н. Қазақстан республикасының ғылыми инновациялық потенциясы және оның

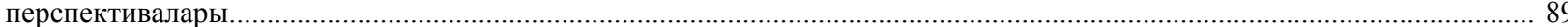

Хамитхан Н. Қазақстандағы банктік қызметтердің сапасын жақсарту жағдайында банкаралык басекелестік............ 95

Шалдарбеков Қ.Б., Муханова Г.С., Нурмухамбетова 3.С. Аймақтарды дамыту бағдарламаларын жүзеге асырудағы жобалық басқаруды қолданудың шетелдік тәжірибесі

КаратаеваА.М., Бердиярова Ж.С. Мемлекеттік қызметшінің әдептік мәдениеті және құқықтық мәдениеті

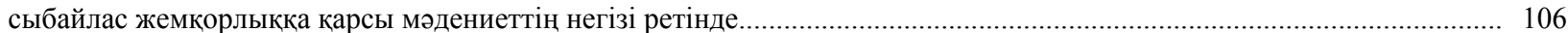

Алдабергенова А.А. Абсурд әдебиетін аударудың лингвомәдени аспектілері ................................................... 113

Стукач В. Ф., Байдалинова А. С., Сандыбаева Б. А. Қазақстанның қаржылық қауіпсіздігі......................................... 119

Баймаханова Д.М., Оспанова Д.А. Конституциялық-құқықтық сана - конституционализмнің маңызды

компоненті ретінде және оның адам құқықтары мәселелерін шешудегі рөлі................................................................. 126

Имангожина 3.А. Сланцевая революция: глобальный тренд на мировом энергетическом рынке............................. 137

Ракаева А.Н., Жуматаева Б.А., Успамбаева М.К., Доскалиева Б.Б. Экологиялық есеп қазақстандағы кәсіпорын экономикасының даму кезеңі ретінде

Нуржанова Г.И. Экономиканың аграрлық секторындағы еңбек әлеуетіне демографиялық фактордың әсері............ 147

Оспанова Д.А., Баймаханова Д.М. Қазақстан Республикасының кибер кеңістігін дамыту жағдайында мемлекеттік қызметтерді цифрландыруда әкімшілік-құқықтық қамтамасыз ету ................................................................................... 152

Pblсnекова М.О., Тлесова Э.Б., Хаитбаева Ф.К. Қазақстандағы тұрғын үй-коммуналдық шаруашылық қызметін

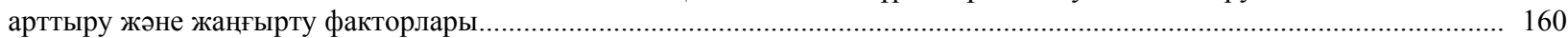

Султанова Г. Т. Аграрлық сектордың экспорттық әлеуетін дамытуға бағытталған үрдістер мен басымдықтар........ 166 


\section{СОДЕРЖАНИЕ}

Алтыбаева С.М., Сагындыков Е.С. Культурный код и мифопоэтическое моделирование в структуре художественного текста.

Сембиева Л.М., Мажитов Д.М., Карпиикая М.Е., Хамитова Д.М. Трансформация монетарной системы стран

ЕАЭС в условиях модернизации экономики.............................................................................................................

Кулсариева А.T., Султанова М.Э., Шайгозова Ж.Н. Фольклор и идентичность: история, память и мифотворчество

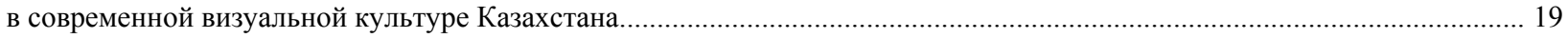

Кенжебаев Д.А. Полигон Сарышаган - краткий исторический анализ................................................................ 26

Абдулина Г.А., БазарбаевА.Г. Современные концепции управления человеческми ресурсами в организациях........... 33

Агыбаев А.Н., Адибаева А.К. Имплементационные механизмы Конвенции ООН о геноциде в уголовных

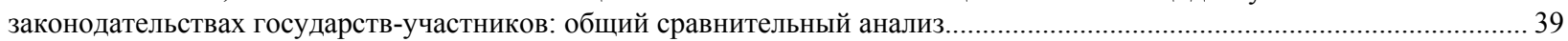

Ахметжанов Б., Тажибекова К.Б., Шаметова А.А. Анализ развития угольной промышленности Казахстана........... 44

Аюпова 3.К., Кусаинов Д.У.Проблемы конституционно-правового развития республики Казахстан в условиях

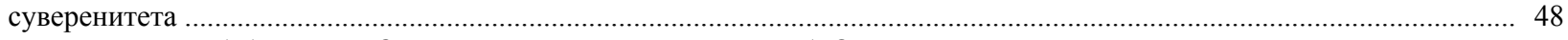

Нурпеисова А.А., Рей И.Ю., Бижанов Д.Т., Тлеужанова Д.А. Основные элементы управления процессом создания

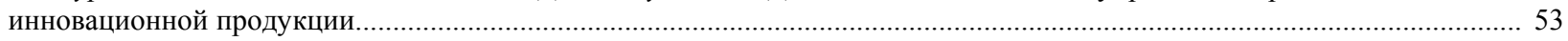

Гиздатов Г.Г. Психолингвистическое исследование концептов казахстанского дискурса...................................... 57

Ищанова Р.К. Управление государственными расходами - как обеспечение финансовой устойчивости государства. 64

Мадымева А.М. Бикенова А.С., Елеусиз Л.Т. Туристские услуги в сфере образования........................................... 68

Ескалиева А. Ж., Баймуханова М.Т., Ахмурзина Д.О. Перспективы усиления качества человеческого капитала

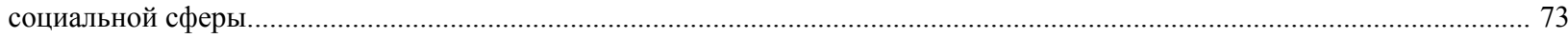

Мархаева Б.А., Козбахова Д.Л. Центр ответственности и трансфертное ценообразование..................................... 79

Сабирова Р.К., Утепкалиева К.М., Кабаков С.Б. Экологические аспекты экономики сельского хозяйства

в Казахстане........................................... 85

Тлесова Э., Хойч А., Кураш Н. Научно-инновационный потенциал республики Казкастан и его перспективы............ 89

Хамитхан Н. Межбанковская конкуренция в условиях повышения качества банковских услуг в Казахстане.............. 95

Шалдарбеков К.Б., Муханова Г.С., Нурмухамбетова 3.С. Зарубежный опыт применения проектного управления

при реализации программ развития регионов

Каратаева А.М., Бердиярова Ж.С. Этическая культура и правовая культура государственных служащих

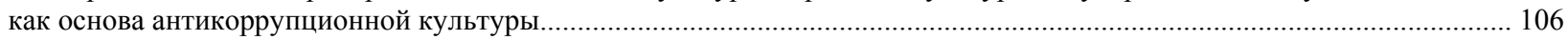

Алдабергенова А.А. Лингвокультурологические аспекты перевода литературы абсурда.......................................... 113

Стукач В. Ф., Байдалинова А. С., Сандыбаева Б. А. Казахстанская финансовая безопасность.................................... 119

Баймаханова Д.М., Оспанова Д.А. Конституционно-правовое сознание как важный компонент конституционализма

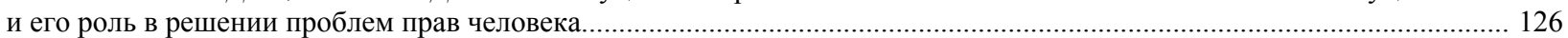

Имангожина 3.A. Сланцевая революция: глобальный тренд на мировом энергетическом рынке............................. 137

Ракаева А.Н., Жуматаева Б.А., Успамбаева М.К., Доскалиева Б.Б. Экологический учет как ступень развития

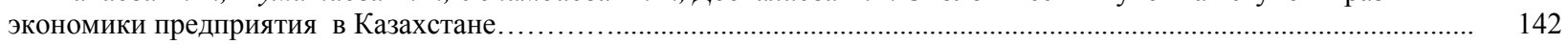

Нуржанова Г.И. Влияние демографического фактора на трудовой потенциал аграрного сектора экономики............ 147

Оспанова Д.А., Баймаханова Д.М. Административно-правовое обеспечение цифровизации государственных услуг

в условиях развития кибер пронстранства республики Казахстан..

Pыспекова М.О., Тлесова Э.Б., Хаитбаева Ф.К. Факторы инновационной модернизации и совершенствования

деятельности жилищно-коммунального хозяйства в Казахстане.

160

Султанова Г. Т. Тенденции и приоритеты развития экспортного потенциала аграрного сектора................................ 166 


\section{CONTENTS}

Altybayeva S.M., Sagyndykov E.S. Cultural code and myth poetic modeling in the structure of the artistic text..................... 5 Sembiyeva L.M., Mazhitov D.M., Karpitskaya M.E., Khamitova D.M. Transformation of the monetary system of the eurasian economic UNION countries in the conditions of modernization of the economy......

Kulsarieva A.T., Sultanova M.E., Shaigozova Zh.N. Folklore and identity: history, memory and myth-making in the modern

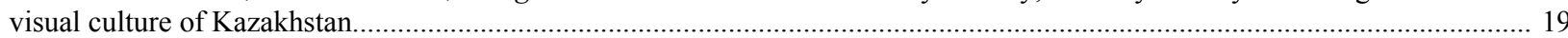

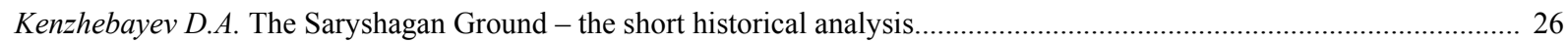

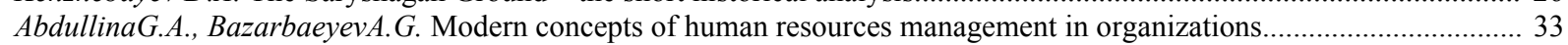

Agybayev A.N., Adibayeva A.K. Implementing mechanisms of the UN Convention on genocide in the criminal legislation

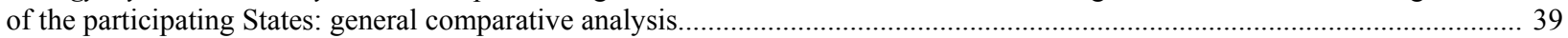

Akhmetzhanov B., Tazhibekova K.B, Shametova A.A. Analysis of development of the coal industry of Kazakhstan.............. 44 Ayupova Z.K., Kussainov D.U. Problems of constitutional and legal development of the republic of kazakhstan in the conditions of sovereignty......

Nurpeisova A.A., Rey I.Yu., Bizhanov D.T., Tleuzhanova D.A. Main elements of managing the process of creating innovation production.

Gizdatov G.G. Psycholinguistic study of the concepts of Kazakhstar

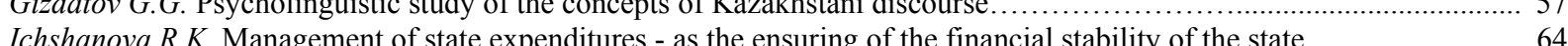

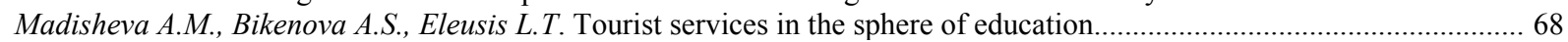

Eskalieva A. Zh., Baymukhanova M.T., Ahmurzina D.O. Perspectives of strengthening the quality of the human capital

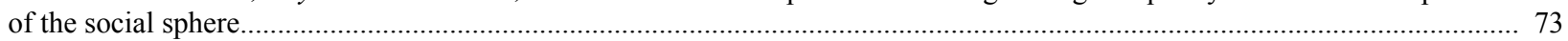

Markhayeva B.A., Kozbakhova D.L. A responsibility center and transfer pricing ................................................. 79

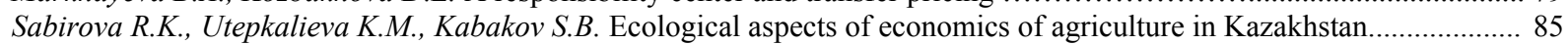

Tlessova E., Khoich A., Kurash N. Scientific innovation potential of the republic of Kazkahstan and its perspectives........ 89

Hamitkhan $N$. Interbank competition in conditions of improving the quality of banking services in Kazakhstan.................. 95

Shaldarbekov K., Mukhanova G., Nurmukhambetova Z. International practices in project management in implementing

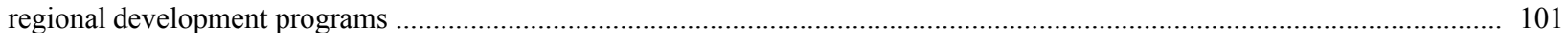

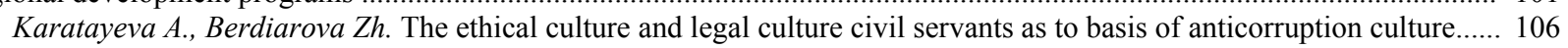

Aldabergenova A.A. Linguocultural aspects of translation of absurd literature.............................................................. 113

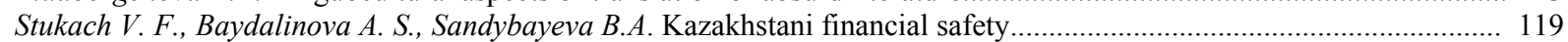

Baimakhanova D.M., Ospanova D.A. Constitutional and legal consciousness as an important component of constitutionalism

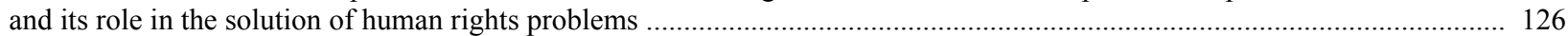

Imangozhina Z.A. Shale gas revolution: global trend in the world energy market..................................................... 137

Rakaeva A.N., Zhumataeva B.A., Uspanbayeva M.K., B.B.Doskalieva. Level of ecological report development in the economic of Kazakhstan's companies.

Nurzhanova G.I. Impact of demographic factors on labor potential of economy's agricultural sector

Ospanova D.A., Baimakhanova D.M. Administrative and legal support of digitalization of public services in the context of the development of cyber space in the republic of Kazakhstan....

Ryspekova M.O., Tlessova E.B., Khaitbayeva F. Factors of innovative modernization and improvement of activity

of housing and communal services in Kazakhstan.

Sultanova G. T. Trends and priorities for the development of export potential of the agrarian sector. 


\title{
PUBLICATION ETHICS AND PUBLICATION MALPRACTICE IN THE JOURNALS OF THE NATIONAL ACADEMY OF SCIENCES OF THE REPUBLIC OF KAZAKHSTAN
}

For information on Ethics in publishing and Ethical guidelines for journal publication see http://www.elsevier.com/publishingethics and http://www.elsevier.com/journal-authors/ethics.

Submission of an article to the National Academy of Sciences of the Republic of Kazakhstan implies that the work described has not been published previously (except in the form of an abstract or as part of a published lecture or academic thesis or as an electronic preprint, see http://www.elsevier.com/postingpolicy), that it is not under consideration for publication elsewhere, that its publication is approved by all authors and tacitly or explicitly by the responsible authorities where the work was carried out, and that, if accepted, it will not be published elsewhere in the same form, in English or in any other language, including electronically without the written consent of the copyrightholder. In particular, translations into English of papers already published in another language are not accepted.

No other forms of scientific misconduct are allowed, such as plagiarism, falsification, fraudulent data, incorrect interpretation of other works, incorrect citations, etc. The National Academy of Sciences of the Republic of Kazakhstan follows the Code of Conduct of the Committee on Publication Ethics (COPE), and follows the COPE Flowcharts for Resolving Cases of Suspected Misconduct (http://publicationethics.org/files/u2/New Code.pdf). To verify originality, your article may be checked by the originality detection service Cross Check http://www.elsevier.com/editors/plagdetect.

The authors are obliged to participate in peer review process and be ready to provide corrections, clarifications, retractions and apologies when needed. All authors of a paper should have significantly contributed to the research.

The reviewers should provide objective judgments and should point out relevant published works which are not yet cited. Reviewed articles should be treated confidentially. The reviewers will be chosen in such a way that there is no conflict of interests with respect to the research, the authors and/or the research funders.

The editors have complete responsibility and authority to reject or accept a paper, and they will only accept a paper when reasonably certain. They will preserve anonymity of reviewers and promote publication of corrections, clarifications, retractions and apologies when needed. The acceptance of a paper automatically implies the copyright transfer to the National Academy of sciences of the Republic of Kazakhstan.

The Editorial Board of the National Academy of sciences of the Republic of Kazakhstan will monitor and safeguard publishing ethics.

Правила оформления статьи для публикации в журнале смотреть на сайте:

$$
\begin{gathered}
\text { www:nauka-nanrk.kz } \\
\text { social-human.kz }
\end{gathered}
$$

\author{
Редакторы М.С. Ахметова, Т.А. Апендиев, Д.С. Аленов \\ Верстка на компьютере А.М. Кульгинбаевой \\ Подписано в печать 10.10.2018 \\ Формат 60x881/8. Бумага офсетная. Печать - ризограф. \\ 11,6 п.л. Тираж 500. Заказ 5.
}

